\title{
APLIKASI MODEL LIMA KEKUATAN PORTER PADA RESTORAN DRUPADI
}

\author{
Sevenpri Candra \\ Management Department, School of Business Management, BINUS University \\ Jln. K. H. Syahdan No 9, Palmerah, Jakarta Barat 11480 \\ scandra@binus.edu
}

\begin{abstract}
Internet is one of the global information dissemination media. It provides an easy way of doing business and facilitating users to communicate and obtain information needed quickly and accurately with the use of the website. To view the competition within the industry, the author uses Porter Five Forces Analysis method. By Porter analysis, it showed the bargaining power of consumers in strong position. Consumer satisfaction can be achieved by providing quality products and good services. So that, the Internet service, which is a global market with 24-hour nonstop access, can be used as a media campaign and can provide information to customers.
\end{abstract}

Keywords: website, Porter Five Forces Analysis

\begin{abstract}
ABSTRAK
Internet adalah salah satu media penyebaran informasi global, yang memberi kemudahan dalam berbisnis dan mempermudah pemakainya untuk berkomunikasi serta memperoleh informasi yang dibutuhkan dengan cepat dan akurat dengan penggunaan situs web.Untuk melihat persaingan dalam satu industry, penulis mengunakan metode analisis lima kekuatan porter (Porter Five Forces Analysis). Dengan analisis Porter, terlihat bahwa kekuatan tawar menawar dari konsumen berada dalam posisi yang kuat. Kepuasan konsumen dapat dicapai dengan memberikan kualitas produk dan pelayanan yang baik. Dengan layanan Internet yang merupakan pasar global yang sangat besar dengan akses 24 jam tanpa henti, sehingga dapat dimanfaatkan sebagai media promosi serta menyediakan informasi bagi pelanggan.
\end{abstract}

Kata kunci: situs web, Model Lima Kekuatan Porter 


\section{PENDAHULUAN}

Di era teknologi informasi kebutuhan akan informasi yang cepat dan akurat menjadi suatu harapan bukan saja bagi konsumen tetapi juga bagi perusahaan. Informasi yang cepat dan akurat dapat dilakukan dalam bentuk suatu situs web. Situs web dapat diakses melalui Internet. Menurut Kotler \& Armstrong (2010), Internet adalah jaringan global yang luas dan terus berkembang dari jaringan komputer, tanpa manajemen pusat atau kepemilikan. Internet dikembangkan pada akhir 1960-an oleh Departemen Pertahanan AS, yang pada awalnya untuk menghubungkan laboratorium pemerintah, kontraktor, dan instalasi militer. Sekarang, Internet menghubungkan para pengguna komputer di seantero dunia.

Perkembangan jumlah pengguna Internet di Indonesia sejak tahun 2000 mengalami peningkatan terus menerus. Sedangkan saat ini data terbaru untuk 2011 menunjukkan pengguna Internet di Indonesia berjumlah 39 juta orang. Oleh karena itu, teknologi Internet telah menjadi suatu hal yang diperlukan dalam dunia bisnis baik di perusahaan, sekolah, universitas, bahkan dalam kehidupan sehari-hari di rumah. Internet, sebagai salah satu media penyebaran informasi global, memberikan kemudahan dalam berbisnis dan mempermudah pemakainya untuk berkomunikasi serta memperoleh informasi yang dibutuhkan dengan cepat dan akurat dengan penggunaan situs web.

Umumnya, perusahaan memiliki situs web yang memuat informasi mengenai gambaran perusahaan tersebut, termasuk di antaranya berisi tentang perusahaan dan produk yang ditawarkan. Penggunaan situs web juga dapat membantu perusahaan dalam segi pemasaran, sehingga jangkauan strategi pemasarannya dapat meluas, termasuk pada perusahaan yang bergerak di bidang restoran. Salah satu contoh kasusnya adalah Restoran Drupadi. Bagaimana kondisi situs web yang saat ini sudah dimiliki oleh Restoran Drupadi dibandingkan dengan situs web yang dimiliki oleh restoran lain yang sejenis?

Website adalah perangkat lunak sistem yang memudahkan sistem yang berbeda untuk berkomunikasi satu sama lain secara otomatis untuk mendapatkan informasi atau melakukan transaksi. Seorang pengecer dan pemasok, misalnya, sangat mungkin menggunakan website untuk berkomunikasi melalui public Internet dan secara otomatis memperbarui sistem masing-masing (McKinsey, 2007).

Model Lima Kekuatan Porter diperkenalkan oleh Michael Porter (1980) dan telah dimodifikasi dan disebarkan ke lainnya. Model lima kekuatan Porter (seperti pada Gambar 1) tentang analisis kompetitif adalah pendekatan yang digunakan secara luas untuk mengembangkan strategi dalam banyak industri. Menurut Porter (1980), hakikat persaingan suatu industri dapat dilihat sebagai kombinasi atas lima kekuatan yaitu yaitu persaingan di antara perusahaan sejenis, kemungkinan masuknya pendatang baru, potensi pengembangan produk substitusi, kekuatan tawar-menawar pembeli serta kekuatan tawar-menawar pemasok. Kelima kekuatan persaingan ini menentukan intensitas persaingan dan profitabilitas dalam industri, dan kekuatan yang paling besar akan menentukan perumusan strategi. Porter dalam (David, 2011) melihat hakikat suatu industri sebagai kombinasi atas lima kekuatan: 


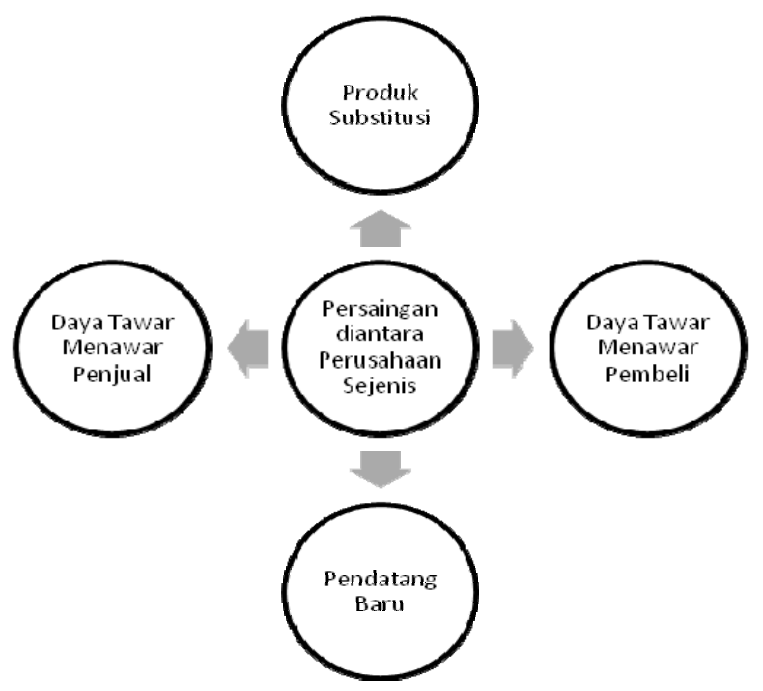

Gambar 1 Model Lima Kekuatan Porter

\section{Persaingan Perusahaan Sejenis}

Persaingan antarperusahan sejenis biasanya merupakan kekuatan terbesar dalam lima kekuatan kompetitif. Strategi yang dijalankan oleh suatu perusahaan dapat berhasil hanya jika mereka memberikan keunggulan kompetitif dibanding strategi yang dijalankan perusahaan pesaing. Perubahan strategi oleh satu perusahaan mungkin akan mendapat serangan balasan, seperti menurunkan harga, meningkatkan kualitas, menambah fitur, menyediakan jasa, memperpanjang garansi, dan meningkatkan iklan.

\section{Pendatang Baru}

Ketika perusahaan baru dapat dengan mudah masuk ke industri tertentu, intensitas persaingan antarperusahaan meningkat. Akan tetapi, hambatan untuk masuk, dapat mencakup kebutuhan untuk mencapai skala ekonomi dengan cepat, kebutuhan untuk mendapatkan teknologi dan pengetahuan khusus, kurangnya pengalaman, tingginya kesetiaan pelanggan, kuatnya preferensi merek, besarnya kebutuhan akan modal, kurangnya jalur distribusi yang memadai, peraturan pemerintah, tarif, kurangnya akses terhadap bahan mentah, kepemilikan paten, lokasi yang kurang menguntungkan, serangan balasan dari perusahaan yang sudah mapan, dan potensi kejenuhan pasar.

\section{Potensi Pengembangan Produk Substitusi}

Pada banyak industri, perusahaan bersaing dekat dengan produsen produk substitusi dalam industri yang berbeda. Keberadaan produk substitusi menciptakan batas harga tertinggi yang dapat dibebankan sebelum konsumen beralih ke produk substitusi. Tekanan kompetisi yang berasal dari produk substitusi meningkat sejalan dengan menurunnya harga relatif dari produk substitusi dan sejalan dengan biaya konsumen untuk beralih ke produk lain menurun, cara terbaik untuk mengukur kekuatan kompetitif produk substitusi adalah dengan memantau pangsa pasar yang didapat oleh produk tersebut, juga dengan memantau rencana perusahaan untuk meningkatkan kapasitas dan penetrasi pasar.

\section{Daya Tawar-menawar Penjual/Pemasok}

Kekuatan tawar-menawar pemasok memengaruhi intensitas persaingan dalam suatu industri, khususnya ketika ada sejumlah besar pemasok, ketika hanya ada sedikit barang substitusi yang cukup 
bagus, atau ketika biaya untuk mengganti bahan baku sangat mahal. Sering kali kepentingan yang dicari oleh pemasok dan produsen adalah saling memberikan harga yang masuk akal, memperbaiki kualitas, mengembangkan jasa baru, pengiriman just-in-time, dan mengurangi biaya persediaan, dengan demikian memperbaiki profitabilitas jangka panjang untuk semua pihak. Perusahaan dapat menjalankan strategi integrasi ke belakang untuk mendapatkan kendali atau kepemilikan dari pemasok.

\section{Daya Tawar-menawar Pembeli/Konsumen}

Ketika konsumen terkonsentrasi atau besar jumlahnya, atau membeli dalam jumlah besar, kekuatan tawar-menawar mereka menjadi kekuatan utama yang memengaruhi intensitas persaingan dalam suatu industri. Perusahaan pesaing mungkin menawarkan garansi yang lebih panjang atau jasa khusus untuk mendapatkan kesetiaan pelanggan ketika kekuatan tawar-menawar konsumen (bargaining power of consumer) cukup besar. Kekuatan tawar-menawar konsumen juga lebih tinggi ketika yang dibeli adalah produk standar atau tidak terdiferensiasi. Ketika kondisinya seperti ini, konsumen sering kali dapat bernegosiasi tentang harga jual, cakupan garansi dan paket aksesori hingga ke tingkat yang lebih tinggi.

Setelah manajer mampu menilai kelima kekuatan tersebut, dan menentukan ancaman dan peluang yang ada, maka strategi untuk menghadapi persaingan pun dapat dipilih. Menurut Porter, tidak ada perusahaan harus memilih strategi yang dapat memberikan keunggulan kompetitif bagi perusahaan tersebut.

\section{METODE PENELITIAN}

Penelitian ini mengunakan analisis Five Porter Forces untuk dilakukan analisis industri sejenis. Diharapkan dengan analisis, maka dapat diketahui kondisi eksternal persaingan di industri restoran dan terutama pada industri yang sejenis. Sehingga dari hasil ini, perusahaan dapat membuat suatu strategi bersaing terkait dengan situs web yang dimiliki.

\section{HASIL DAN PEMBAHASAN}

Restoran Drupadi berdiri sejak Februari, 2011. Asal mula restoran ini dinamakan Drupadi adalah terjemahan bahasa Indonesia dari Draupadi, seorang pahlawan dalam Mahabharata, seorang wanita yang kuat yang menolak untuk menjadi korban keadaan. Diceritakan dalam wiracarita Mahabharata, Draupadi lahir dari api, berkemauan keras, dan pahlawan penuh kasih dengan keindahan yang tak tertandingi dan kecerdasan.

Restoran ini bangga untuk menggunakan nama karakter wanita terbesar dalam Mahabharata untuk bisnisnya; restoran yang menyajikan masakan Chinese dengan cita rasa Indonesia. Restoran Drupadi bersemangat dan penuh kasih dalam melayani pelanggannya. Makanan tidak mengandung daging babi dan menghindari penggunaan MSG penambah rasa buatan karena beberapa orang alergi terhadap hal itu.

Drupadi terletak di daerah komersial Jababeka, melayani makanan favorit lokal dan asia. Kapasitas tempat duduk saat ini adalah 40 kursi dan pengembangan masa depan akan meningkatkan kapasitas hingga 80 kursi. Harga rata-rata makanan adalah Rp. 15.000. Saat makan siang, konsumen utama adalah pekerja dan saat sore hari menjadi tempat bergaul pemuda dan pemudi setempat. 
Untuk menganalisis kondisi bisnis pada Restoran Drupadi digunakan analisis Porter yang berfungsi untuk mengetahui kondisi lingkungan sekitar bisnis dari lima kekuatan, yaitu potensi pengembangan produk, produk pengganti, kekuatan pemasok, kekuatan pembeli, dan persaingan antarperusahaan sejenis. Hasil analisis dari model lima kekuatan Porter dapat dilihat pada Gambar 2.

\section{Persaingan Perusahaan Sejenis}

Keadaan persaingan perusahaan yang sejenis dengan Restoran Drupadi saat ini dapat dikatakan cukup kompetitif. Persaingan antarrestoran sejenis merupakan ancaman yang sangat besar bagi perusahaan. Banyak restoran lain yang sejenis yang sudah berdiri sebelum Drupadi berdiri. Contoh Restoran pesaing adalah Es Teler 77, Solaria, Waroeng Mbok-De yang sama-sama menjual makanan yang sejenis.

Persaingan antarrestoran pesaing merupakan ancaman yang sangat besar bagi Restoran Drupadi. Namun Restoran Drupadi mempunyai keunggulan tersendiri yang belum tentu dimiliki oleh restoran-restoran pesaing, seperti Restoran Drupadi melayani katering harian untuk rumah-rumah dan juga katering untuk karyawan kantor dan pabrik sekitar.

\section{Kemungkinan Masuknya Pesaing Baru}

Jenis bisnis yang dijalankan oleh Restoran Drupadi adalah sebuah bisnis yang sangat rentan dengan masuknya pendatang baru karena pada bisnis ini sangat mudah untuk perusahaan baru untuk masuk ke pasar. Ancaman pendatang baru yang harus diperhatikan oleh pihak Restoran Drupadi adalah Restoran Gule Kepala Ikan Mas Agus, Restoran Ayam Trancam, RM. Pendopo

\section{Potensi Pengembangan Produk Substitusi}

Kehadiran produk substitusi menjadi ancaman bagi setiap perusahaan yang sudah beroperasi dalam industri. Restoran Drupadi memiliki produk substitusi seperti Restoran Padang, Warteg, Warung Tenda.

\section{Daya Tawar Menawar Pemasok/Penjual}

Bahan baku yang digunakan Restoran Drupadi untuk memproduksi makanan yang dijual di restoran merupakan bahan yang banyak beredar di pasar, sehingga relatif mudah untuk didapatkan, sehingga daya tawar dari pemasok cenderung rendah. Yang menjadi pemasok bahan baku Restoran Drupadi yaitu : Gas Elpiji: PD. Jaya Electric; Bakso , Mie, Saos: Toko Maju Jaya; Beras: UD. Kembang; Air Mineral Galon , Teh Botol , Stee , Fanta, Coca-cola, Sprite: Toko Sama Jaya; Sayur Mayur: UD. KDI Sayur

\section{Daya Tawar Menawar Konsumen/Pembeli}

Karena banyaknya penyedia jasa restoran yang menawarkan berbagai macam masakan yang ditawarkan kepada konsumen, maka kekuatan tawar menawar konsumen sangat berpengaruh terhadap keberhasilan perusahaan. Konsumen merupakan salah satu faktor penghasil laba perusahaan. Selain itu, konsumen juga memiliki banyak pertimbangan terhadap sejumlah restoran pesaing yang menjual makanan sejenis atau makanan yang berbeda jenis dengan yang ditawarkan oleh Restoran Drupadi, serta konsumen memiliki kontribusi yang besar terhadap total penjualan perusahaan. Oleh karena itu, hubungan antara perusahaan dengan konsumen harus tetap terjaga dengan baik guna meningkatkan loyalitas dan kepuasan mereka. Yang merupakan pembeli di Restoran Drupadi adalah karyawan yang bekerja di kantor-kantor sekitar restoran, warga sekitar, kantor/pabrik sekitar. 
Berikut ini adalah gambar hasil analisis untuk Restoran Drupadi dengan menggunakan model Lima Kekuatan Porter.

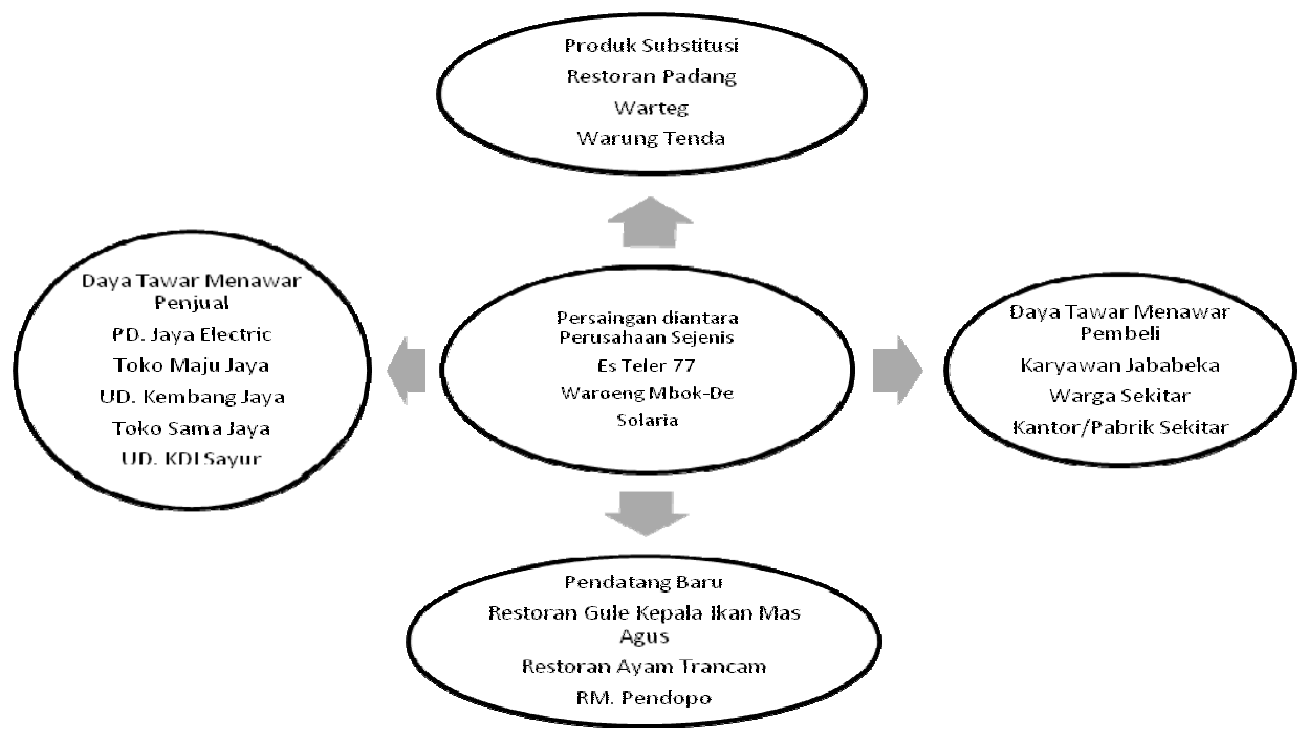

Gambar 2 Hasil Analisis Model Lima Kekuatan Porter Untuk Restoran Drupadi Sumber: (Ligyaningtyas \& Candra, 2012)

\section{SIMPULAN}

Berdasarkan hasil analisis Porter di atas, pada persaingan perusahaan sejenis, perusahaan memiliki strategi dengan menciptakan competitive advantage. Pada kemungkinan masuknya pesaing baru, perusahaan memiliki strategi dengan menciptakan barrier to entry. Pada potensi pengembangan produk substitusi, strateginya dengan melakukan inovasi menu. Pada kekuatan tawar menawar pemasok, strateginya dengan strategi backward. Pada kekuatan tawar menawar, strategi yang diterapkan perusahaan adalah dengan meningkatkan pelayan kepada pelanggan, melakukan kerja sama terhadap pelanggan dengan memberikan diskon khusus kepada pelanggan yang memesan dalam jumlah besar, misalnya untuk acara-acara. Berdasarkan hasil di atas, disimpulkan bahwa perusahaan telah memiliki strategi-strategi untuk bersaing. Oleh karena itu, perusahaan dapat bersaing dalam industri tersebut.

Dengan analisis Porter terlihat bahwa kekuatan tawar menawar dari konsumen dapat dikatakan berada dalam posisi yang kuat. Kepuasan konsumen dapat dicapai dengan memberikan kualitas produk dan pelayanan yang baik. Oleh karena itu, perusahaan harus berfokus pada kepuasan konsumen dengan cara meningkatkan layanan dengan mengembangkan pemasaran melalui Internet. Layanan Internet yang merupakan pasar global yang sangat besar dengan akses 24 jam tanpa henti sehingga dapat dimanfaatkan sebagai media promosi serta menyediakan informasi bagi pelanggan. Untuk itu Restoran Drupadi diharapkan untuk mengembangkan website yang sudah ada dalam menunjang tujuan dan memberikan informasi serta meningkatkan kepuasan yang lebih terhadap pelanggan. 


\section{DAFTAR PUSTAKA}

David, F. R. (2011). Strategic Management: Concepts and Cases. $13^{\text {th }}$ ed. New Jersey: Pearson.

Kotler, P. \& Armstrong, G. (2010). Principles of Marketing. $13^{\text {th }}$ ed. New Jersey: Pearson.

Laudon, K. \& Traver, C. G. (2013). E-commerce. $9^{\text {th }}$ ed. New Jersey: Prentice Hall.

Ligyaningtyas, M. I. K. \& Candra, S. (2012). Analisa dan Pemgembangan Situs Web Pada Restoran Drupadi, Universitas Bina Nusantara - Jakarta: Skripsi Tidak Dipublikasi.

McKinsey. (2007). How companies are marketing online: A McKinsey Global Survey. Retrieved $9^{\text {th }}$ July 2012 from http://www.sata.ca/file/HowCompaniesAreMarketingOnline.pdf 